Сміянов В.А., Курганська В.О.

\title{
Застосування методів поведінкової економіки у боротьбі з COVID-19
}

\author{
Сумський державний університет, м. Суми, Україна
}

vladlor60@ukr.net

\author{
Смиянов В.А., Курганская В.А. \\ Применение методов поведенческой экономики \\ в борьбе с COVID-19 \\ Сумской государственный университет, \\ г. Сумы, Украина
}

Smiianov V.A., Kurhanska V.O.

Application of behavioral economics methods

to help fight COVID-19

Sumy State University, Sumy, Ukraine

\section{Вступ}

Сьогодні у світі існує велика невизначеність щодо масштабів пандемії через передачу коронавірусу, що викликає захворювання COVID-19. Неможливо однозначно спрогнозувати, скільки людей будуть уражені вірусом і скільки з них може померти, проте відомо, що існують певні заходи, які певним чином сповільнюють передачу вірусу i, в кінцевому рахунку, рятують життя [2]. Багато цих заходів пов'язані 3 організацією медичних послуг, а саме: ресурси для відстеження контактних осіб [6], транспортування людей, які потребують тестування, наявність ізоляційних ліжок тощо [5]. Інші базуються на змінах у прийнятті рішень та поведінці громадян: часте миття рук та покращення особистої гігієни в цілому [14], етикет при чханні та кашлі, розуміння, коли і як необхідно самоізолюватися тощо [16]. Останніми роками в світі спостерігається збільшення кількості досліджень в поведінковій науці. У деяких країнах світу ця наука все частіше застосовується у вирішенні проблем політики урядами та міжнародними організаціями [12].

Останніми місяцями повсякденне життя людей в усьому світі, i Україна, нажаль, не є виключенням, сповнено інформацією про передачу коронавірусу, захворюваність та смертність від COVID-19, проте необхідно розуміти та прогнозувати, що контекст та подача інформації впливають на прийняття рішень та поведінку більшості людей. Базуючись на даних про нелінійну динаміку зараження, можна припустити, що сповільнення передачі вірусу може в кінцевому рахунку знизити загальну кількість контактних осіб, а відповідно і осіб, які заразилися.

Метою даного дослідження було вивчення сукупності прикладних наукових знань та доказів, які впливають на рішення людей та їх поведінку та можуть бути застосовані у боротьбі з COVID-19.

\section{Матеріали та методи}

Структура дослідження включала: висвітлення основних питань профілактичної боротьби з коронавірусом, 3 урахуванням знань та методів поведінкової економіки (миття рук, дотики до обличчя, питання соціального дистанціювання, заохочення до колективних дій, уникнення небажаної поведінки та сприйняття ризику), які були розроблені на основі власних досліджень (метод соціального експерименту, анкетування) 3 подальшою статистичною обробкою даних за допомогою ліцензійного пакету програм «ОСА» (обробка соціологічних анкет), яка $\epsilon$ комп'ютерною програмою аналізу первинної соціологічної інформації, а також на основі найбільш актуальних даних світової літератури.

\section{Результати дослідження та їх обговорення}

Захворюваність на COVID-19 є найбільшою 3 теперішніх загроз як здоров'ю людей, так і світовій економіці. Враховуючи відсутність на сьогоднішній день вакцини проти цього захворювання, профілактика $\epsilon$ єдиним доступним заходом для зменшення невиправних наслідків.

Миття рук. Втручання в зміну поведінки людей повинні подолати поширений та істотний бар'єр - звички. Звички діють здебільшого поза свідомістю, відповідно їх важко змінити шляхом покращення освіти та обізнаності. Навіть в умовах загостреної ситуації в сфері охороні здоров'я, такої як епідемія інфекційного захворювання, спроби покращити гігієну рук та інші способи боротьби 3 інфекцією через освіту та обізнаність мають обмежений та короткочасний вплив. Також варто зазначити, що значна частина досліджень проводиться в лікарнях та інших медичних установах, тоді як відповідь у боротьбі 3 COVID-19 вимагає змін поведінки також у будинках, на робочих місцях, в громадських будівлях, тощо.

Нами були проведені експериментальні дослідження за участю студентів 3 курсу медичного 
інституту Сумського державного університету, результати яких свідчать про те, що важливим аспектом успішних втручань у гігієну рук населення $є$ привертання уваги до санітарного засобу для рук на основі спирту у громадських місцях. Результати показали, що у продуктових магазинах самообслуговування відвідувачі в 2,6 разів частіше $(\mathrm{p}<0,05)$ використовують санітайзери на основі спирту для обробки рук, коли дозатори розташовані біля кошиків для продуктів, ніж коли вони знаходяться біля камер схову чи інших місцях 3 меншою візуалізацією. Окрім місця розташування, відмічається груповий ефект, відповідно до якого відвідувачі, які заходили до магазину вдвох, частіше застосовували санітайзери (у 1,87 рази, р<0,05), ніж покупці, які були поодинці. Також нами був проведений експеримент, в якому біля дозатора із антисептичним засобом був розташований миготливий ліхтарик червоного кольору з метою привернення уваги до засобу для обробки рук. Даний метод вплинув на поведінку людей та на їх рішення, підвищивши частоту обробки рук покупцями ще на 1,17 ( $\mathrm{p}<0,05)$.

Отже, було встановлено, що на дотримання гігієни рук можуть впливати такі фактори, як видимість та доступність дозаторів. Більш видимі, близькі та зручні місця їх розташування, а також додаткове привернення уваги до флаконів збільшують частоту їх використання. Поширене використання даних методів у громадських місцях може суттєво вплинути на поведінку громадян, зменшивши можливість передачі вірусу.

Дотики до обличчя. Деякі дослідження свідчать про те, що люди торкаються рота, носа чи очей, біля 10 20 разів на годину [7]. Нами було встановлено, що використання масок для індивідуального захисту зменшує кількість дотиків до обличчя. Це довели проведені нами дослідження, за даними яких згідно анкетування 46,7\% ( $<<0,05)$ опитаних помітно рідше, за їх спостереженнями, торкались руками обличчя, перебуваючи на вулиці чи в інших громадських місцях, а 27,6\% (p<0,05) проанкетованих осіб взагалі відмічають відсутність дотиків до обличчя в період, коли вони перебувають в масці.

Наявність факту торкання обличчя викликає питання, як заохотити людину до конкретної поведінки за відсутності очевидної наочності. На нашу думку, зміна поведінки базується на моделі, що складається 3 трьох основних елементів: здатності, можливості та мотивації. Здатність передбачає як психологічні (наприклад, знання та вміння виконувати певну дію), так і фізичні (сила та витривалість) здібності. Можливість включає як соціальні (наприклад, норми), так і фізичні (наприклад, ресурси) сприяючі сторони. Мотивація включає як «рефлексивні» (наприклад, свідоме прийняття рішень), так і «автоматичні» (наприклад, емоції та звички) процеси. Ці поведінкові впливи взаємодіють між собою наступним чином:

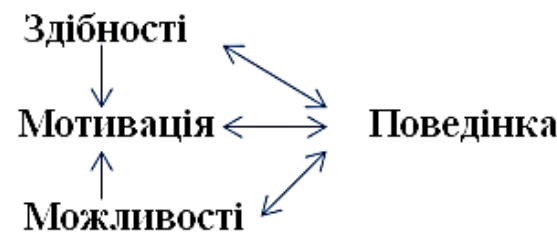

Пандемічний спалах COVID-19 формує та надає унікальний набір обставин і проблем, при якому кожна рекомендована захисна поведінка буде змінюватися залежно від здібностей, можливостей та/або мотивації, необхідних для їх широкого застосування. Розуміння цих впливів $\epsilon$ ключовим фактором для розробки ефективних стратегій для забезпечення змін. Необхідно зазначити, що тільки освіти та підвищення інформованості населення не достатньо. Потрібні зміни фізичного та соціального середовища, а також розуміння та мислення.

Що стосується дотику до обличчя, фізичним втручанням в цьому випадку може бути розміщення серветок на помітних місцях, наприклад. безпосередньо перед клавіатурою для офісних працівників, за обіднім та журнальним столиками, щоб люди могли використовувати їх з метою купувати свербіж в ділянці обличчя. Соціальні втручання можуть полягати в рекомендаціях органів охорони здоров'я до певної зміни соціальної прийнятності, а саме, чесання рукавом, а також в порадах чхати або кашляти в лікті або передпліччя, а не в руку.

Соціальне дистанціювання. Частиною необхідної відповіді на спалах COVID-19 є обмеження соціальних контактів, особливо 3 тими особами, у яких наявні відповідні симптоми або підвищений ризик зараження вірусом. Хоча самоізоляція може допомогти стримувати та контролювати поширення інфекційних захворювань, ізоляція має важливі негативні психологічні наслідки. Усвідомлення цих наслідків важливо з метою допомогти людям підготуватися до них або, при можливості, запобігти їм. Поведінкові науки також припускають, що передбачення цих ефектів може вплинути на більш усвідомлене дотримання самоізоляції.

В літературі з психології та громадського здоров'я можна зустріти дані, що свідчать про те, що соціальна ізоляція має згубні наслідки для самопочуття. Соціальне дистанціювання також пов'язане 3 підвищеним ризиком виникнення проблем у психічному здоров'ї, включаючи депресію та тривожність [3], виснаженість та дратівливість, що відбувається через відсутність соціальних контактів, втрату свободи та нудьги під час карантину. Самоізоляція також може мати певні довгострокові ефекти, включаючи депресивні симптоми [8] та надбання шкідливих звичок [18]. Тривалість ізоляції має важливе значення. Більш тривалі періоди призводять до гірших наслідками психічного здоров'я, а подовження періоду ізоляції після первинних припущень може деморалізувати людей та підвищити ризик недотримання режиму. Отже, чіткість та визначеність термінів мають важливе значення.

Також варто відмітити, що небезпека полягає і в тому, що відчуття негативних наслідків ізоляції можуть перешкоджати добровільному виконанню соціальних та особистих зобов'язань. Приймаючи рішення відносно того, чи слід брати участь у заходах, запропонованих міністерством охорони здоров'я, люди враховують не лише їх сприйнятливість до загрози та її серйозність, але і те, наскільки ефективною у боротьбі з проблемою, на їх думку, буде запропонована модель поведінки. Деякі люди 
свідомо уникають отримання важливої медичної інформації в ситуаціях, коли вона може призвести до небажаної активності. Так, відомим є факт, що більшість людей уникає, інформації, яка сповіщає їх про можливу необхідність оперативного втручання.

Згідно 3 результатами проведеного нами дослідження, з 315 осіб, які взяли участь в експерименті, $71,7 \% \quad(\mathrm{p}<0,05) \quad$ людей висловлюють небажання ізолюватися, коли постає питання про шанс заразити інших, оскільки вони мають певні сумніви щодо можливості зараження осіб, які з ними контактують, проте близько $86 \%(p<0,05)$ опитаних людей заявляють про готовність до самоізоляції, коли мова йде про можливий вплив на найуразливіші прошарки суспільства (похилі люди, особи 3 хронічними захворюваннями, імунодефіцитними станами та ін.) та можливість їх зараження. Отже, варто відмітити, що люди, передбачаючи негативні наслідки самоізоляції та відчуваючи певний страх від них, можуть недооцінити або взагалі свідомо приховати симптоми COVID-19, з метою уникнення можливої ізоляції.

Допомогти людям впоратися 3 негативними наслідками під час ізоляції може планування часу. Плани краще робити та виконувати, якщо вони конкретні за часом та наочні, а не узагальнені. Створення планів перед ізоляцією, обговорення їх 3 іншими та поєднання їх із загальноприйнятим розпорядком може допомогти людям подолати тривогу.

Заохочення колективних дій. Поведінкова реакція на COVID-19 є неминуче колективною. Кожна людина ризикує випадково заразитися вірусом i цей ризик залежить не тільки від їх власної поведінки, але і від поведінки інших співгромадян. Наявні дані доводять, що молоді люди мають значно менший ризик заразитися та захворіти на COVID-19, ніж люди похилого віку [17], проте все ж таки готовність змінити власну поведінку, в свою чергу, впливатиме на те, скільки людей похилого віку отримують вірус. Існують дослідження, які демонструють те, що частина людей зневажають власний інтерес та діють в колективних інтересах. Вони $\epsilon$ «умовними кооператорами», тобто тими, хто готов робити жертви на суспільне благо за умови, що інші громадяни теж дотримуються такої ж позиції, та відповідно, припиняють співпрацю, якщо інших людей не турбує дане питання. Така поведінкова взаємодія частіше має місце при надзвичайних ситуаціях [11].

У поведінці, в основі якої лежить громадська відповідальність мають місце три основних фактора: інформованість, групова ідентичність та покарання. Однозначним $є$ те, що співпраця часто істотно покращується, за допомогою комунікації. Співпраця посилюється за допомогою чітких заяв, сформульованих лідерами про бажану колективну поведінку, що відповідає інтересам групи 3 подальшим неодноразовим їх повторенням. Це може посилити довіру серед громадян, встановити соціальні норми та спонукати людей дотримуватися певної поведінки. Спостереження за ефективною комунікацією, яка стоїть перед соціальною дилемою, виявляє, що найбільше підтримує співпрацю та взаємодію саме висловлювання того, яка модель поведінки найкраще для всіх, a не переконання здійснювати конкретну поведінку [13]. Отже, найефективнішим формулюванням аргументів для сприяння дотриманню ізоляції є те, що самоізоляція - найкращий спосіб для всіх громадян запобігти зараженню одне одного. Чим більше людей відчуває себе частиною групової чи громадської взаємодії, тим більше шансів на самовіддані вчинки людей. Співпраця $є$ більш імовірною, коли існує прозорість щодо внесків людей та покарання тих, хто не виконує своїх громадських обов'язків. Покарання не обов'язково має бути матеріальним, а може полягати у соціальному несхваленні [4]. Ці докази, що стосуються колективних дій, мають суттєве значення у боротьби 3 COVID-19. Дана ситуація $є$ колективною не тільки на міжнародному та національному рівнях, але і в межах місцевостей, робочих місць та у побуті.

Уникнення небажаної поведінки. Нехтування миттям рук, порушення встановлених норм при кашлі чи чхання або уникнення самоізоляції при перших справжніх ознаках симптомів являє собою погану модель індивідуальної поведінки відносно ідеальних стандартів у відповідь на епідемію коронавірусу. Тим не менше, цю поведінку необхідно відрізняти від більш антисоціальних форм, серед яких можна виділити панічні реакції, невиправдані вираження гніву в адресу чиновників чи медичних працівників, ксенофобні реакції на людей, раси чи національності, які сприймаються як високоризикові, або неадекватні реакції на тих, хто заразився вірусом. Обнадіюючими є дослідження, які показують, що взаємна допомога $є$ більш поширеною реакцією на кризу, ніж масова паніка та соціальний розлад [10]. Тим не менше, у відповідь на спалах хвороби все таки можуть виникнути певні соціальні та економічні порушення. 3 певною періодичністю людям доводиться стикатися 3 безвідповідальним висвітленням інформації у засобах масової інформації та його впливом на громадськість. На початку пандемії мала місце недоброзичлива, тривожна подача інформації, відповідно до якої вірус, який викликає захворювання COVID-19, презентувався суспільству як «вірус-вбивця», що безумовно впливало на психологічний стан більшості людей. Необхідно відмітити, що на сьогоднішній день, нажаль, немає якісних доказів щодо рушійних сил панічної скупівлі товарів серед людей по всьому світу та, відповідно, iї попередження, проте можна зробити припущення, що у виникненні цієї проблеми також певну роль відіграє некоректність подачі інформації. Незважаючи на свою назву, панічна скупка промислових товарів не завжди викликана сильними емоціями та може також бути природньою реакцією людей, які схильні уникати ризиків, на загрозу майбутньої відсутності товарів або відсутності можливості доступу до них (наприклад, через ізоляцію) [15]. Фактично, накопичення запасів демонструє антисоціальну модель поведінки в масштабній проблемі «спільного використання ресурсів».

Отже, чітке управління та регулярні заяви про неприйнятність зазначеної поведінки $є$ необхідними, як частина колективної реакції суспільства разом із видимим 
покаранням людей, які не додержуються встановлених норм та правил поведінки в умовах пандемії.

Сприйняття ризику. Основна роль уряду країни під час пандеміі - інформування громадян про можливі ризики. 3 точки зору поведінки, це складна галузь, оскільки сприйняття ризиків громадянами часто $\epsilon$ необ'єктивним. Заниження ризику може підірвати зусилля, спрямовані на зміну громадської поведінки, а їх завищення може призвести до збільшення економічних та соціальних витрат, а також панічно налаштувати суспільство. оскільки різні люди мають різну толерантність до ризику. Еталонної реакції на певний рівень ризику немає. Органи влади повинні якомога вірніше та точніше повідомляти громадськості про небезпеку, пов'язану з COVID-19. Дане припущення грунтується на декількох переконливих фактах. По-перше, діяти інакше - антидемократично. Люди повинні покладатися на владу в наданні їм об'єктивної картини, на якій базуються рішення по боротьбі з вірусом. По-друге, довіра $\epsilon$ найважливішим компонентом громадянської поведінки. Перебільшення або заниження ризиків можуть призвести до зменщення довіри, яку конче необхідно зберігати протягом всієї епідемії.

Люди оцінюють ймовірність наслідків певним чином грунтуючись на тому, як це спадає їм на думку «евристика доступності». Ця евристика відхиляє уявлення про смертельний ризик, збільшуючи вірогідність сприятливих результатів та тих, що підкреслюються засобами масової інформації. Ризики здаються більшими, коли інформація має більш емоційне обрамлення «евристичний афект». Страх, як правило, посилює сприйняття ризику, тоді як гнів може зменшувати його. Відомо, що переважна більшість людей краще сприймають та більше довіряють числовій подачі інформації, однак, навіть цифри можна надати таким чином, що ризики будуть здаватися відповідно більшими або меншими [1]. Це базується на позитивному та негативному обрамленні (наприклад, 3\% смертності проти $97 \%$ виживання). Отже, важливим є питанням, яким чином подавати ступінь небезпеки, оскільки вплив COVID-19 на населення всієї планети наразі важко оцінити. Немає безперечного «найкращого досвіду» щодо інформування населення про можливі ризики для здоров'я, проте можливо сформулювати базові рекомендації, основними серед яких $\epsilon$ : не використовувати інформацію про конкретні та екстремальні випадки, уникати емоційної мови (крім вираження співпереживання), максимально об'єктивно використовувати статистичні дані.

Перспективи подальших досліджень пов'язані 3 вивченням результатів застосування методів поведінкової економіки в інших галузях громадського здоров'я.

\section{Висновки}

Втручання, що базується на поведінковій економіці, передбачають, $з$ одного боку, можливість здійснення певних змін в поведінці людей, які можуть перетворити нові звички на більш довгострокові переваги для здоров'я, a 3 іншого - зниження ризику переобтяження системи охорони здоров'я, що є одним з головних питань, які викликають стурбованість, пов'язану з пандемією COVID19. Поведінкові втручання, що ведуть до покращення гігієнічних та профілактичних практик, разом із знаннями про епідеміологію інфекційних захворювань, та уроками, які надає пандемія COVID-19, стануть частиною інструментарію у вирішенні проблеми залишення цієї загрози позаду якнайшвидше.

\section{References}

1. Akl E. A., Oxman A. D., Herrin J., Vist G. E., Terrenato I., Sperati F., Schünemann H. Using alternative statistical formats for presenting risks and risk reductions. Cochrane Database of Systematic Reviews, 3. - 2011. https://doi.org/10.1002/ 14651858.CD006776.pub2.

2. Anderson R. M., Heesterbeek H., Klinkenberg D., Hollingsworth T. D. How will country-based mitigation measures influence the course of the COVID-19 epidemic? // Lancet. - 2020. Published online. https://doi.org/10.1016/S01406736(20)30567-5.

3. Cacioppo J. T., Hughes M. E., Waite L. J., Hawkley L. C., Thisted R. A.. Loneliness as a specific risk factor for depressive symptoms: cross-sectional and longitudinal analyses. Psychology and Aging. - 2006. - Vol. 21(1) P. 140. https://doi.org/10.1037/0882-7974.21.1.140.

4. Fehr E., Gachter S. Cooperation and punishment in public goods experiments // American Economic Review. 2000. - Vol. 90. - P. 980-994. https://doi.org/10.1257/aer.90.4.980.

5. Hanefeld J., Mayhew S., Balabanova D. Towards an understanding of resilience: Responding to health systems shocks // Health Policy and Planning. - 2018. - Vol. 33. - P. 355-367. https://doi.org/10.1093/heapol/czx183.

6. Hellewell J., Abbott S., Zandvoort K. (2020). Feasibility of controlling COVID-19 outbreaks by isolation of cases and contacts // The Lancet Global Health. - 2020. https://doi.org/10.1016/S2214- 109X(20)30074-7.

7. Kwok Y. L. A., Gralton J., McLaws M. L. Face touching: A frequent habit that has implications for hand hygiene // American Journal of Infection Control. - 2015. - Vol. 43. - P. 112-114.

8. Liu X., Kakade M., Fuller C. J., Wu, P. Depression after exposure to stressful events: lessons learned from the severe acute respiratory syndrome epidemic. // Comprehensive psychiatry. - 2012. - Vol. 53(1). - P. 15-23. https://doi.org/10.1016/ j.comppsych.2011.02.003. 
9. Masclet D., Noussair C., Tucker S., Villeval M. C. Monetary and nonmonetary punishment in the voluntary contributions mechanism // American Economic Review. - 2003. - Vol. 93. - P. 366-380.

10. Mawson A. R. Understanding mass panic and other collective responses to threat and disaster // Psychiatry: Interpersonal and Biological Processes. - 2005. - Vol. 68. - P. 95-113. https://doi.org/10.1521/psyc.2005.68.2.95.

11. Moussaïd M., Trauernicht M. Patterns of cooperation during collective emergencies in the helpor-escape social dilemma. Scientific Reports, 6, 33417. - 2016. https://doi.org/10.1038/srep33417.

12. OECD. Behavioural insights and public policy: lessons from around the world. - 2017. Publishing, Paris. http://dx.doi.org/10.1787/9789264270480-en.

13. Pavitt C. The Path to Cooperative Action during Group Social Dilemmas: A Literature Review, Set of Propositions, and Model Describing How the Opportunity to Communicate Encourages Cooperation. Review of Communication Research. 2018. - Vol. 6. - P. 54-83. https://doi.org/10.12840/issn.2255-4165.2018.06.01.016.

14. Rabie T., Curtis V. Handwashing and risk of respiratory infections: A quantitative systematic review // Tropical Medicine \& International Health. - 2006. Vol. 11(3). P. 258-267. https://doi.org/10.1111/j.1365- 3156.2006.01568.x.

15. Savage D. A., Torgler B. Stocking up to prepare for a crisis isn't «panic buying». It's actually a pretty rational choice. Available at: https://theconversation.com/stocking-up-to-prepare-for-a-crisis-isnt-panicbuying-its-actually-a-prettyrational-choice-132437 [Accessed 09/03/2020].

16. Smith R. D. Responding to global infectious disease outbreaks: Lessons from SARS on the role of risk perception, communication and management. // Social Science \& Medicine. - 2006. - Vol. 63. - P. 3113-3123. https://doi.org/10.1016/ j.socscimed.2006.08.004.

17. Sohrabi C., Alsafi Z., Agha R. World Health Organization declares Global Emergency: A review of the 2019 Novel Coronavirus (COVID-19) // International Journal of Surgery. - 2020. Published online. https://doi.org/10.1016/ j.ijsu.2020.02.034.

18. Wu P., Liu X., Fang Y., Litvak I. J. Alcohol abuse/dependence symptoms among hospital employees exposed to a SARS outbreak // Alcohol \& Alcoholism. - 2018. - Vol. 43(6). - P. 706-712. https://doi.org/10.1093/alcalc/agn073.

Дата надходження рукопису до редакції: 08.06.2020 p.

Мета - вивчення сукупності прикладних наукових знань та доказів, які впливають на рішення людей та їх поведінку та можуть бути застосовані у боротьбі з COVID-19.

Матеріали та методи. Структура дослідження включала: висвітлення основних питань профілактичної боротьби 3 коронавірусом з урахуванням знань та методів поведінкової економіки, які були розроблені на основі власних досліджень (метод соціального експерименту, анкетування) 3 подальшою статистичною обробкою даних та на основі найбільш актуальних даних світової літератури.

Результати. В ході експериментальних досліджень та соціальних опитувань доведено, що застосування поведінкових методів у комбінації із профілактичними заходами суттєво впливає на поведінку громадян, зменшуючи можливість передачі вірусу.

Висновки. Втручання, що базується на поведінковій економіці, передбачають, з одного боку, можливість здійснення певних змін в поведінці людей, які можуть перетворити нові звички на більш довгострокові переваги для здоров'я, а з іншого - зниження ризику переобтяження системи охорони здоров'я, що є одним з головних питань, які викликають стурбованість, пов'язану з пандемією COVID-19.

Ключові слова: поведінкова економіка, профілактика, коронавірус, COVID-19.

Цель - изучение совокупности прикладных научных знаний и доказательств, которые влияют на решения людей и их поведение и могут быть применены в борьбе с COVID-19.

Материалы и методы. Исследования включало освещение основных вопросов профилактической борьбы с коронавирусом, применяя знания и методы поведенческой экономики, которые были разработаны на основе собственных исследований (метод социального эксперимента, анкетирование) с последующей статистической обработкой данных и на основе наиболее актуальных данных мировой литературы.

Результаты. В ходе экспериментальных исследований и социальных опросов доказано, что применение поведенческих методов в сочетании с профилактическими мероприятиями существенно влияет на поведение граждан, уменьшая возможность передачи вируса.

Выводы. Вмешательства, основанные на поведенческой экономике, предусматривают возможность осуществления определенных изменений в поведении людей, которые могут превратить новые привычки в более долгосрочные преимущества для здоровья, а также снижение риска перегруженности системы здравоохранения, что является одним из главных вопросов, которые вызывают обеспокоенность, связанную с пандемией COVID-19.

Ключевые слова: поведенческая экономика, профилактика, коронавирус, COVID-19. 
The aim is to study a set of applied scientific knowledge and evidence that influences people's decisions and behavior and can be used in the fight against COVID-19.

Materials and methods. The study included coverage of the main issues of preventive control of the coronavirus, using the knowledge and methods of behavioral economics, which were developed on the basis of own research (social experiment method, questionnaire) with subsequent statistical processing of data and on the most current data in the world literature.

Results. Experimental studies and social surveys have shown that the using of behavioral methods in combination with preventive measures significantly affects the behavior of people, reducing the possibility of transmission of the virus.

Conclusions. Behavioral economics-based interventions allow for certain behavioral changes that can turn new habits into longer-term health benefits and reducing the risk of overburdening the health care system, which is one of the major concerns of the COVID-19 pandemic.

Key words: behavioral economics, prevention coronavirus, COVID-19.

Конфлікт інтересів: відсутній.

Conflicts of interest: authors have no conflicts of interest to declare.

\section{Відомості про авторів}

Сміянов Владислав Анатолійович - д.мед.н., проф., завідувач кафедри громадського здоров'я Сумського державного університету; вул. Римського-Корсакова, 2, м. Суми, Сумська область, 40000, Україна. vladlor60@ukr.net.

Курганська Вікторія Олександрівна - к.мед.н., доц., асистент кафедри громадського здоров'я Сумського державного університету; вул. Римського-Корсакова, 2, м. Суми, Сумська область, 40000, Україна. 